\title{
Early Childhood Metacognitive Learning among Students of Early Childhood Teacher Education
}

\author{
Fadillah \\ TeknologiPendidikan, UniversitasTanjungpura \\ DOI: : $\underline{10.31004 / o b s e s i . v 4 i 2.332}$
}

\begin{abstract}
The purpose of this research is to describe the ability of Early Childhood Teacher Education students to carry out Early Childhood metacognitive learning.By using the developmental research method that refers to the Dick and Carey's model, the following research results are obtained: Based on the teaching of thinking, teaching for thinking and teaching about thinking, early childhood metacognitive learning is planned so that the method and media used are clear, to train students' thinking ability. The implementation of early childhood metacognitive learning is assessed from the teacher's perception, namely students of Early Childhood Education as prospective teachers and from children's perceptions. From the teacher's perception it is believed that early childhood metacognitive learning can start at the age of 2 years old. From the children's perception, early childhood metacognitive learning occurs because of the process of habituation and imitation.
\end{abstract}

Keywords: metacognitive; early childhood; students

\begin{abstract}
Abstrak
Tujuan dari penelitian ini adalah untuk mendeskripsikan kemampuan mahasiswaPendidikan Guru Anak Usia Dini untuk melaksanakan pembelajaran metakognitif padaAnak Usia Dini. Dengan menggunakan metode penelitian perkembangan yang mengacu pada model Dick and Carey, diperolehlahhasil penelitian berikut: Berdasarkan pengajaran pemikiran, pengajaran untuk berpikir dan pengajaran tentang berpikir, pembelajaran metakognitif anak usia dini direncanakan sehingga metode dan media yang digunakan Jelas, untuk melatih kemampuan berpikir siswa. Implementasi pembelajaran metakognitif anak usia dini dinilai dari persepsi guru, yaitu mahasiswaPendidikan Anak Usia Dini sebagai calon guru dan dari persepsi anak. Dari persepsi guru diyakini bahwa pembelajaran metakognitif anak usia dini dapat dimulai pada usia 2 tahun. Dari persepsi anak-anak, pembelajaran metakognitif anak usia dini terjadi karena proses pembiasaan dan peniruan.
\end{abstract}

Kata kunci:Metakognitif; PAUD; Mahasiswa

Copyright (c) 2020 Fadillah

$\triangle$ Corresponding author :

Email Address : dinakartikaputri11@gmail.com (Jl. Rawamangun Muka, Jakarta Timur)

Received 20 November2019, Accepted 21 January 2020, Published 21 January 2020 


\section{INTRODUCTION}

Early Childhood metacognitive learning is carried out by exploring the thoughts in the form of Early Childhood Education students' perceptions as prospective Early Childhood Education teacher based on their sense, as well as the expression of their thoughts. In nonverbal language disclosure, students practice using their thoughts with face sketch drawings, and also the use of sign language. The importance of metacognitive learning provided to Early Childhood Teacher Education studentsisin order to practice higher-order thinking skills that will be transmitted to early childhood students. The results of pre-research on the 6th semester of 2019 students showed only 31\% of students indicated a high-level thinking pattern, measured by the ability to answer questions from peers in class discussions creatively, not only tied to the learning modules available(Panggayuh, 2017).

The data enable research with the formulation of the problem "How to teach Early Childhood metacognitive to Early Childhood Teacher Education students?" This general problem is detailed in specific problems, which start from the ability to plan, implement and obtain learning from Early Childhood Teacher Education students.

To elaborate the answers to the problem formulation, the support of the theory is used that shows that metacognitive is defined as "thinking about thinking"(Murti, 2011). (Dariyanto, 2008)stated that the strategy for determining one's cognitive processes and the way they think about information processing is known as metacognitive strategies. (Scandura, 2016)argued that between the ages of 3 - 5 years old, metamemory and metacognitive knowledge begin to develop, so that metacognitive can be developed. (Costa et al., 2000)examined the theory proposed by Piaget, and stated that a 2-year-old child has chosen withwhom to be bathed, whether mother, or sister, or a nanny. This shows that metacognitive includes a person's thoughts, including young children(Puspitasari et al., 2017)

The importance of Early Childhood Education students to explore metacognitive learning serves as an exercise to equip themselves to be able to transmit the knowledge by developing Early Childhood metacognitive learning(Thayeb \& Putri, 2017).(Murti, 2011) stated that learning so far has not taught many children to have the ability to think. This shows the development of thoughts in children. Because the mind is in the process of developing, the assessment becomes increasingly interesting, although for logical thinking children aged 2 to 6 years old are not ready (Fitri, 2017). However, by using various approaches such as the approach of process skills and problem solving, youngchildren can be trained to think to the metacognitive level. According to Preisseisen as quoted by (Mohiddin, 2018)metacognitive consists of four skills namely decision making, critical thinking, creative thinking, problem solving.

Teaching thinking skills in children is very important to help children achieve the ability to think towards perfection(Fauziddin \& Mufarizuddin, 2018).In early childhood, of course the thinking process is still limited to certain situations. And this requires parents, educators to treat children in order to develop their thinking abilities. In Islamic teachings, teaching thinking skills in children is highly recommended. The method of teaching children is used to fulfill four elements, namely affection, assertiveness, glory and respect (Gloudemans, 2013)which follows the stages of child development. The Messenger of Allah said "Children are kings until the age of seven years, servants in the second seven years and ministers in the third seven years (King, 2010)

Early Childhood metacognitive learning for students as prospective Early Childhood Education teachers is marked by the perceptions or processes of students organizing and interpreting their sensory impressions of everything they perceive, which is limited to face sketches seen and sketching faces according to the mind, followed by language to communicate facial sketches which are observed and made(Chatzipanteli et al., 2014)The theory that underlies this thought emerged from (Bauer,Talya,Erdogan, 2012),(Scandura, 2016)which states that perception is a process of regulating and interpreting sensory 
information to give meaning to sensations. (Risnanosanti, 2008)views learning to include the cognitive domain, affective domain and psychomotor domain. The cognitive domain is concerned withvarious abilities possessed by humans. Affective domain tests the heart which gives birth to feelings, how to behave and to haveattitudes, all of which come from the heart. Psychomotor domain is concerned with a number of skills that humans may have. Facts, definitions, these concepts, all of them are a collection of ideas summarized in theory, so that in learning the theory of learning is born, among which is known as the Behavioristic Learning Theory; CognitivisticTheory; Constructive Learning Theory; Humanistic Learning Theory and Cybernetic Theory. In addition, the Early Childhood learning theoriesare also studied, namely the Vigotsky Theory and the Montessori Theory.

\section{METHODOLOGY}

The research method in this study is research and development (R\&D) that refers to Dick and Carey's model, consisting of ten steps. To answer the research problems that were formulated, the early childhood metacognitive learning procedures are as follows: (a) How to plan Early Childhood metacognitive learning in Early Childhood Teacher Education students? This can be answered from step 1: Identifying learning objectives; Step 2: Analyzing learning; Step 3: Input behavior and characteristics of Early Childhood Teacher Education students; Step 4: Formulating performance goals; and Step 5: Developing assessment points or instruments. (b) How to carry out Early Childhood metacognitive learning in Early Childhood Teacher Education students? This can be answered in step 6: Developingearly childhood metacognitive learning strategies; and Step 7: Determining early childhood metacognitive learning material. (c) How is the acquisition of Early Childhood Teacher Education students' learning outcomes towards early childhood metacognitive learning? This can be answered from step 8: Providing formative tests, whichis an assessment of early childhood metacognitive learning; Step 9: Revision of learning if difficulties or implementation of learning are encountered; and Step 10: Designing a summative test in the form of student learning outcomes.

This research has a single variable which is early childhood metacognitive learning, that is described in the form of behavioral skills and cognitive skills.Behavioral skills are realized by: (a) Exploring the mind in the form of students' perceptions according to their senses by reading the face sketches and writing down the results of the senses of the face sketches. (b) Expressing thoughts in the form of students' perceptions in accordance with their senses, namely students drawing facial sketches and writing down their sensing about the face sketches they draw.

And cognitive skills which inlude: (a) Analyzing metacognitive learning materials for young children. (b) Developing metacognitive learning by reviewing and clarifying the results of research studies published in online journals. (c) Analyzing the learning theoriesfound.

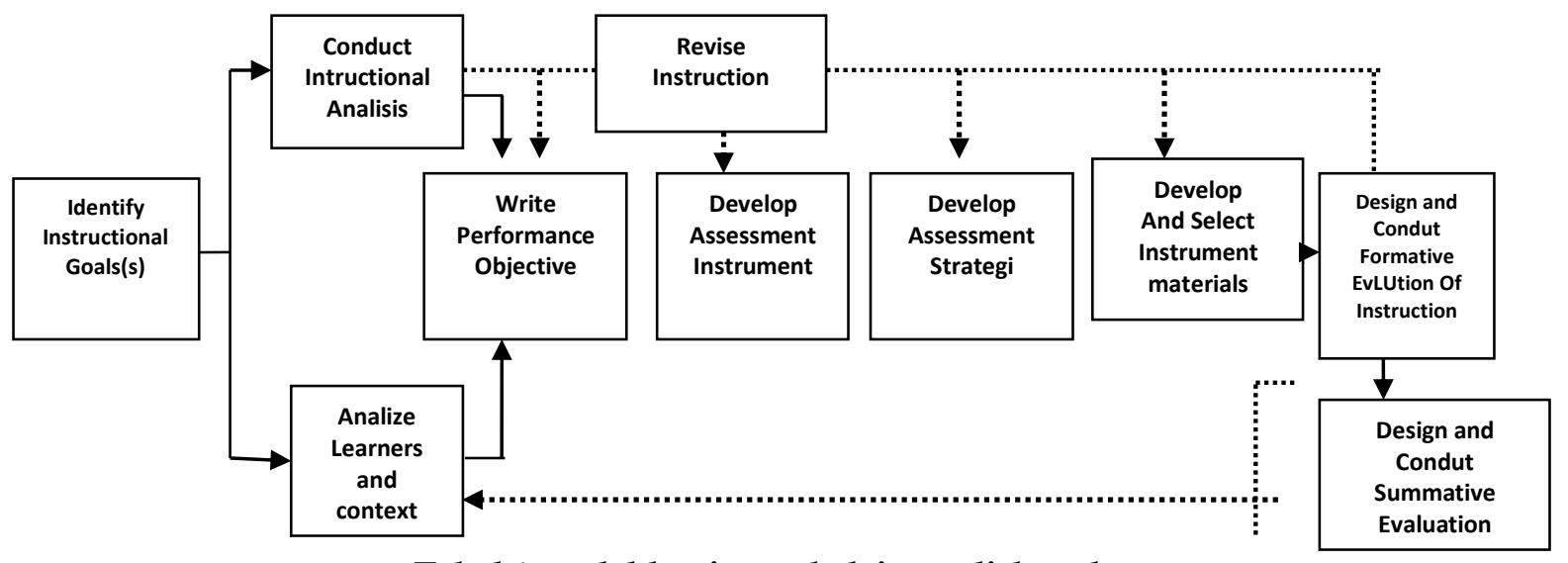

Tabel 1.modeldesainpembelajaran dick and carey 
The populations of this study wereEarly Childhood Teacher Education students who took the course of "Early Childhood Cognitive Development Method", a total of 40 students. Because the population is not too large, all population members are sampled.The data collection techniques used were observation techniques with observation sheets, measurement techniques with tools in the form of tests.The data analysis was performed qualitatively, for mind reading data from students' perception, and quantitatively for data obtained from formative test results aimedat students.

\section{RESULT AND DISCUSSION}

\section{Planning of Early Childhood Metacognitive Learning}

Instructional planning refers to the goal in which students master the principles of early childhood metacognitive learning and can train children to develop their mind. Selftraining to work as a teacher is carried out by students by training the mind based on sensing perceptions as a realization of metacognitive learning, which is supported by metacognitive learning theories.

Student outcomes of Early Childhood metacognitive learning are implemented in accordance with learning material, planned for 5 weeks, with the following studies:

Week 1: Early Childhood metacognitive learning, with learning activities as follows: (a) Listening to the importance ofintroducingEarly Childhood metacognitive learning; (b) Exploring the mastery of Early Childhood metacognitive learning, with questions and answers; (c) Group work that explores the results of Early Childhood metacognitive learning research with expository, brain storming and collaborative learning methods.

Week 2: With the observation based learning method, students perceive based on their senses, in the form of observing face sketches and writing down everything. According to senses. Next is the expression of thought. Students who see a face sketch, are provided with the material to draw a face sketch in accordance with theirownthoughts, and the method used is brain storming.

Week 3: Evaluation of observation material and facial sketch expressions and writing everything according to each student's senses and thought.

Week 4: Literature review from online journals, with collaborative learning method, they hold group discussion of Early Childhood metacognitive learning research results and supporting theories of learning, then continue to havea class discussion

Week 5: The attitude of mastery of Early Childhood metacognitive learning material using the assignment method

The skills that must be possessed by Early Childhood Teacher Education students are the final achievements of each stage of learning, including preparation of media, communicating thoughts that can be poured into drawing or sketching or translating sketches.

Therefore, the purpose of performance is that students are equipped with cognitive skills in the form of mastery of Early Childhood metacognitive learning materials, Early Childhoodof metacognitive learning theories, Early Childhood metacognitive learning related to Early Childhood characteristics.

\section{The implementation of Early Childhood Metacognitive Learning}

Metacognitive Learning is carried out by reviewing the metacognitive learning materials of young children in terms of cognitive skills and behavioral skills as well as literature studies. The results are as follows: (a) High-level thinking among students shows that only $31 \%$ are marked by the ability to answer creatively, not only tied to the available learning modules. (b) In terms of doing assignments in the form of preparing learning media that is thought to be suitable and feasible, students still need examples to emulate. (c) The task of presenting the results of reading, many are in the form of text,and have not been able to make a concept map for the material being discussed. 
From the behavioral skills in terms of emotional intelligence,the results of research related to self-intelligence which is manifested in behavioral skills are presented as follows: (a) The results of sensing carried out by students on the observation of 40 face sketches show a burst of positive emotions of $42 \%$ in the form of a smile, firmness with a smile, happiness, humor, conversations about good food, agreement, laughter that is not forced and not excessive, mocking despite pleasure for oneself and sneaky smile. Negative emotions by $37 \%$ in the form of annoyance and anger and full of emotion, sadness, confusion, anger, perplexity, being upset, fear or anxiety, surprise, badmood, anger, and mocking others. Flat emotions of $21 \%$ are close to unawareness, in the form of drowsiness, fatalism, numbness or unwillingness and no longer being able to speak, listening to others. (b) Thinking with oneself expressed through face sketches made by Early Childhood Education students. Of the 37 students present at the time of the study, 14 students or $38 \%$ drew face sketches with happy emotion, while $62 \%$ drew facial sketches describing sad emotion.

The results of the study of literature studies, about the theory of learning in Early Childhood metacognitive learning, are:

\section{Behavioristic learning theory.}

The reason: a child's metacognitive ability does not appear by itself but is trained into habits. The exercise process is done by playing.The theory of learning to investigate metacognitive abilities and the ability to interact based on age and environment independently is provided by teachers by introducing different strategies and practicing them. It means that it requires stimuli from the teacher.The teacher plays an important role for the child's success in solving problems. And the teacher always improves cognitive strategies for more complex problems. The teacher's role is to reflect metacognitive learning and problem solving by increasing cognitive knowledge and regulation of cognitive behavior.

\section{Theory of cognitivism}

The reason: the teacher plays a major role in trainingstudents' metacognitiveskills and helps children develop metacognitive awareness and identify factors that enhance metacognitive development by using media of games in learning, such as mixing colors, blocks, bombixes and sand.

\section{Theory of constructivism}

The reason:since metacognitive ability develops with age,knowledge of the existence of thoughts and the content of thoughts (beliefs, desires and intentions) are as good as the ability to use this knowledge to predict and explain human actions. Young chldrenare able to use knowledge processes in their life, such as attention, perception, memory and imagination. All these knowledge processes can be obtained from TV, books, the internet and adults. But in building their knowledge, stories about the truth are sometimes accompanied by a few lies, because of their mixed imagination.

\section{Constructivistic and cognitive theories}

The reason: effective strategies for developing cognitive skills and academic performance are done by students studying in groups with their peers.

\section{The learning outcomes of Early Childhood Education students inEarly Childhood} metacognitivelearning are measured by cognitive skills and behavioral skills.

The cognitive skills are measured from: (a) Presentation of Early Childhood metacognitive learning materials and the ability to explain the results of class discussions is mastered by $74 \%$ of students which is categorized as being high. (b) Mid-semester exam results by 38 students are summative to midterm results, which are in the high category of $47 \%$. (c) The results of the final semester exams by 38 students constitute the summative 
results of one semerter which belongs to the low category of $39 \%$, and only $32 \%$ belonging to highcatagory.

\section{The learning outcomes of Early Childhood Teacher Education student in metacognitive learning in terms of behavioral skills were carried out by exploring student attitudes (attachment 4)}

The results are as follows:Most of the Early Childhood Teacher Education students or $56 \%$ strongly agree and agree thatmetacognitive learning is provided to them. And 44\% disagreed and even strongly disagreed.The Early Childhood Teacher Education students'receptionof the concept of metacognitive learning is mostly already good, meaning that $99 \%$ of themacquired the concept of Early Childhood metacognitive learning. The mastery of Early Childhood learning theories was 100\%.In addition to mastering learning theory, students also prepare themselves as Early Childhood Education teachers for other things. 95\% of students realized that they should prepare themselves with knowledge related to Early Childhood Education. But there are 5\% of 6th semester Early Childhood Teacher Education students who were not too concerned with their readiness as Early Childhood Education teachers

Early Childhood metacognitive learning is a set of cognitive development methodology and early childhood science. Therefore, the planning certainly refers to the course's semester instructional plan. Various learning methods such as the expository method, brain storming, observation-based learning, problem-based learning, collaborative learning and assignments are used for this instruction, because there is no one method that is most appropriate for all types of instruction.

The implementation of Early Childhood Metacognitive Learningwascarried out by presenting Early Childhood Metacognitive Learning.Regarding the definition of metacognitive as "thinking about thinking", the implementation of metacognitive learning is related to the process and results of thinking about achievement of learning objectives. It means it is necessary to activate the regulation of interaction and orchestrate cognitive processes, as expressed by (King, 2010) in the review of the theory. The process and results of metacognitive thinking include a person's thoughts, includingyoung children, because the children's metacognitive abilities develop since age 2, when they realize the existence of thoughts (Bauer,Talya,Erdogan, 2012)For example: Children aged 2 have been able to choosewho they want to take a bath with. If it is usually the mother who bathes him, it could be one day that the child wants to take a bath with his older sibling.

With regard to Early Childhood Teacher Educationstudents' learning outcomes, viewed from the attitude of students who consider the importance of Early Childhood metacognitive learning, there were $44 \%$ who disagreed and even strongly disagreed. It is suspected that there are still Early Childhood Teacher Education students who are not too concerned with readiness as Early Childhood Education teachers

\section{CONCLUSION}

This planning includes mastering the material to meet the final achievements of each learning phase. The mastery of Early Childhood learning materials includes theories of learning and Early Childhood learning, learning methods, forms of learning as well as learning media. Self-training to work as a teacher can beachievd by training the mind based on sensing perceptions, having knowledge of the principles of Early Childhood metacognitive learning, and being supported by learning theory in metacognitive learning as well as students' perceptions of sensing as a realization of metacognitive learning. The implementation of Early Childhood Metacognitive Learning was conducted by reviewing Early Childhood metacognitive learning materials and literature studies.The teacher plays a major role in providing metacognitive skills and helps children develop metacognitive awareness by using game media and various different strategies practiced in groups with 
peers.Early Childhood Teacher Education students' learning outcomesof metacognitive learning weremeassured by exploring the students' attitudes, which stated that they strongly agreed and agreedthat metacognitive learning is given to them. In addition, students realize the need to prepare themselves as Early Childhood Education teachers by preparing themselves with knowledge related to early childhood education.

\section{ACKNOWLEDGMENT}

The author thanks all parties who have given their consent and assisted the researcher during the data collection process. The author also thanks the supervisor who helped the researcher in perfecting the results of this study. Acknowledgments were also conveyed to the editorial team of the Obsession Journal who provided suggestions, criticisms, and recommendations for the improvement of this article.

\section{REFERENCES}

Bauer,Talya,Erdogan, B. (2012). Esensi Metode Montessori dalam Pembelajaran Anak Usia Dini (Issue 1).

Chatzipanteli, A., Grammatikopoulos, V., \& Gregoriadis, A. (2014). Development and evaluation of metacognition in early childhood education. Early Child Development and Care, 184(8), 12231232. https:/ / doi.org/10.1080/03004430.2013.861456

Costa, C., Dijkema, C., Friedrich, M., García-Encina, P., Fernández-Polanco, F., \& Stams, A. J. M. (2000). Denitrification with methane as electron donor in oxygen-limited bioreactors. Applied Microbiology and Biotechnology, 53(6), 754-762. https://doi.org/10.1007/s002530000337

Dariyanto. (2008). Early childhood education journal. The Absorbent Mind, Pikiran Yang Mudah Menyerap, Maria Montessori, Yogyakarta, Pustaka Pelajar. http:/ / search.ebscohost.com/login.aspx?direct=true\&db=eue\&AN=130896756\&site=eds-live

Fauziddin, M., \& Mufarizuddin, M. (2018). Useful of Clap Hand Games for Optimalize Cogtivite Aspects in Early Childhood Education. Jurnal Obsesi : Jurnal Pendidikan Anak Usia Dini, 2(2), 162. https://doi.org/10.31004/obsesi.v2i2.76

Fitri, R. (2017). Metakognitif pada Proses Belajar Anak dalam Kajian Neurosains. Jurnal Pendidikan (Teori Dan Praktik), 2(1), 56. https://doi.org/10.26740/jp.v2n1.p56-64

Gloudemans, H. A. (2013). Critical thinking and self-efficacy Useful concepts in nursing practice and education Critical thinking and self-efficacy. Useful concepts in nursing practice and education.

King, L. A. (2010). The Sience of Psychology An Appreciative Vieu.

Mohiddin, D. P. (2018). Pengaruh Pendekatan Metakognisi Terhadap Kemampuan Pemecahan Masalah Matematika Mahasiswa Mesin Dan Peralatan Pertanian Politeknik Gorontalo. Jurnal Teknologi Informasi Indonesia (JTII), 3(1), 12. https:/ / doi.org/10.30869/jtii.v3i1.181

Murti, H. A. S. (2011). Metakognisis dan theory of mind (ToM). Jurnal Psikologi Pitutur, 1(2), 53-64. https:/ / doi.org/10.1080/01426391003746549

Panggayuh, V. (2017). Pengaruh Kemampuan Metakognitif Terhadap Prestasi Akademik Mahasiswa Pada Mata Kuliah Pemrograman Dasar. JIPI (Jurnal Ilmiah Penelitian Dan Pembelajaran Informatika), 2(1), 20-25. https://doi.org/10.29100/jipi.v2i1.228

Puspitasari, D. R., Yuliati, L., \& Kusairi, S. (2017). Keterkaitan antara Pola Keterampilan Berpikir dengan Penguasaan Konsep Siswa pada Pembelajaran Strategi Metakognisi Berbantuan Thinking Map. Indonesian Journal of Applied Physics, 4(02), 142. https://doi.org/10.13057/ijap.v4i02.4978

Risnanosanti. (2008). Kemampuan Metakognitif Siswa Dalam Pembelajaran Matematika. Pythagoras Jurnal Pendidikan Matematika, 4(1), 86-98. https://doi.org/10.21831/pg.v4i1.690

Scandura. (2016). Essentials of Organizational Approach, An Evidence Based Approach. In Thousand Oaks: SAGE Publications.

Thayeb, T., \& Putri, A. P. (2017). Kemampuan Metakognisi Untuk Meningkatkan Keterampilan Pemecahan Masalah Matematika Siswa Kelas Viii B Mts Madani Alauddin Paopao Kabupaten Gowa. MaPan, 5(1), 1-17. https:/ /doi.org/10.24252/mapan.2017v5n1a1 